\title{
POTENSI EKONOMI DAN PENGELOLAAN SAMPAH PASAR DI KOTA BANDAR LAMPUNG
}

Imam Santosa ${ }^{1^{\star},}$ Enro Sujito ${ }^{2}$

${ }^{1}$ Departmen of Environmental Health, Poltekkes Kemenkes Tanjungkarang

\section{Artikel Info : \\ Received 10 Agustus 2020 Accepted 30 Desember 2020 Available online 31 Desember 2020}

Editor: Mey Ahyanti

Key word :

Solid waste, economic potential, Reuse, Reduce, Recycle

Kata Kunci :

Sampah, potensi ekonomi, Reuse, Reduce, Recycle

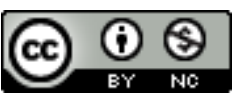

Ruwa Jurai: Jurnal Kesehatan Lingkungan is licensed under a Creative Commons Attribution-NonCommercial 4.0 International License.

\begin{abstract}
A bstract
Market's solid waste that has accumulated can cause air pollution in the form of an odor that disturbs market visitors, traders, and residents around the market. Solid waste that has accumulated is a breeding place for disease vectors, such as flies, cockroaches, and mosquitoes. This research aims to solve the problem of market waste management in the city of Bandar Lampung. Primary data obtained from survey results and direct measurements, namely the volume of waste generation, type of waste, and the composition of waste. Secondary data were obtained from market managers. Market waste management has not used the concept of waste reduction and waste management mandated in the Bandar Lampung City Laws and Regulations, the average amount of waste generation throughout the market is $46,747 \mathrm{~kg} /$ day, the average per day of each market ranges from 3,438-11,703 kg/day. The type and composition of waste is an organic waste of $84.48 \%$ and inorganic waste of $15.52 \%$. The economic potential of all market waste is Rp. $12,938,816 /$ day or Rp. 388,164,480/month and Rp. 4,657,973,760/year. It is necessary to plan $3 R$ TPS and socialize waste management following the mandate of Law No. 18 of 2008 concerning Waste Management, as well as the Regional Regulation of the City of Bandar Lampung No. 5 of 2015 concerning Waste Management in the City of Bandar Lampung.
\end{abstract}

Sampah yang menumpuk dapat menimbulkan pencemaran udara berupa bau yang menyengat sehingga mengganggu pengunjung pasar, pedagang dan penduduk di sekitar pasar. Sampah yang menumpuk merupakan tempat bersarang vektor penyakit, seperti lalat, kecoa dan nyamuk. Penelitian bertujuan untuk memecahkan permasalahan pengelolaan sampah pasar di Kota Bandar Lampung. Data primer diperoleh dari hasil survey dan pengukuran langsung, yaitu volume timbulan sampah, jenis sampah, dan komposisi sampah. Sedangkan data sekunder diperoleh dari pengelola pasar. Pengelolaan sampah pasar belum menggunakan konsep pengurangan sampah dan penanganan sampah yang diamanahkan dalam Undang-Undang dan Peraturan Daerah Kota Bandar Lampung, Jumlah timbulan sampah rata-rata seluruh pasar adalah 46,747 kg/hari, rata-rata per hari masing-masing pasar berkisar antara 3,438-11,703 kg/hari. Jenis dan komposisi sampah adalah sampah organik sebesar $84,48 \%$, dan sampah anorganik sebesar 15,52 \%. Potensi ekonomi seluruh sampah pasar sebesar Rp. 12.938.816/hari atau Rp. 388.164.480/bulan dan Rp. 4.657.973.760/tahun. Perlu dilakukan perencanaan TPS $3 R$ dan sosialisasi pengelolaan sampah sesuai dengan amanat UndangUndang No. 18 Tahun 2008 tentang Pengelolaan Sampah, serta Peraturan Daerah Kota Bandar Lampung No. 5 Tahun 2015 tentang Pengelolaan Sampah di Kota Bandar Lampung

* Corresponding author: Imam Santosa

J. Soekarno-Hatta No 6, Bandar Lampung, Provinsi Lampung

Email : imamsantosa2811@gmail.com

\section{PENDAHULUAN}

Sampah perkotaan merupakan salah satu permasalahan kompleks yang dihadapi oleh Bandar Lampung. Dewasa ini, Kota Bandar Lampung memiliki pasar yang tersebar di seluruh wilayah kota sebagai Unit Pelaksana

Teknis Daerah (UPTD) Kota Bandar Lampung. Adapun pasar-pasar tersebut adalah Pasar Panjang, Pasar Cimeng, Pasar Kangkung, Pasar Tamin, Pasar Gintung, Pasar Smep, Pasar Bawah, Pasar Tugu, dan Pasar Way Kandis. 
Residu atau limbah (sampah) merupakan sumber pencemaran yang merupakan bagian yang tidak terpisahkan dari aktivitas ekonomi dan akan meningkat sejalan dengan peningkat65 vitas tersebut. Oleh karenanya, pencemaran merupakan fenomena yang bersifat pervasive (akan tetap ada) sebagai akibat dari aktivitas ekonomi. Dalam sudut prinsip ekonomi sumberdaya, jalan terbaik dalam menangani pencemaran adalah bagaimana mengendalikan pencemaran tersebut ke tingkat yang paling efisien (Dewi, 2008; Fauzi, 2006; Purwaningrum, 2016).

Nilai ekonomi sampah pasar di Kota Bandar Lampung akan terjadi apabila pengelolaan sampah pasar sudah menggunakan konsep Reduce, Reuse, Recycle (3R). Dengan konsep 3R akan diproleh sampah hasil pemilahan sehingga didapat sampah organik dan non organik. Sampah yang sudah dipilah mempunyai harga jual sampah yang bermanfaat secara ekonomi. Berdasarkan penelitian BPPT, komponen sampah yang mempunyai nilai tinggi untuk dimanfaatkan kembali adalah sampah kertas, logam dan gelas (Oswarii T, Suaryanto DA, 2006).

Pemerintah telah mengeluarkan UU Pengelolaan Sampah No. 18 tahun 2008 yang mendorong adanya pengelolaan sampah langsung dari sumbernya. Sumber sampah berdasarkan UU tersebut adalah asal dari timbulan sampah, seperti rumah tangga, pasar, industri, pusat perbelanjaan, perkantoran dan sebagainya. UU Pengelolaan Sampah tersebut juga menjelaskan pentingnya kegiatan $3 R$ (Reduce Reuse, Recycle) agar volume sampah tidak terus bertambah

Pengelolaan sampah di Kota Bandar Lampung perlu pemikiran lebih lanjut bagaimana mengurangi jumlah sampah pasar dengan memanfaatkan kembali sampah melalui konsep 3R, sekaligus sebagai usaha untuk mengurangi pencemaran air, tanah dan udara. Sehingga sampah pasar yang semula tidak berharga, menjadi memiliki nilai ekonomi setelah dimanfaatkan kembali melalui konsep 3R. Penelitian bertujuan untuk menilai potensi ekonomi dari pengelolaan sampah yang berasal dari pasar-pasar di Kota Bandar Lampung, serta membuat model pengolahan sampah dengan konsep 3R.

\section{METODE}

Melakukan pengumpulan data primer yaitu: 1) Melakukan pengambilan dan pengukuran volume timbulan sampah dengan cara mengukur dan mencatat volume sampah di TPS, menimbang dan mencatat berat sampah, memilah sampah berdasarkan komponen jenis sampah, menimbang dan mencatat berat sampah; 2) Menghitung komponen komposisi sampah dengan cara menimbang sampah total, memilah sampah sesuai karakteristik, menimbang masing-masing sampah, menghitung komposisi sampah; 3) Pengelompokan berdasarkan sampah yang dapat membusuk (Organik,) dan sampah yang tidak membusuk (Non Organik; 4) Menghitung berat jenis sampah $\left(\right.$ Berat jenis $=$ Berat $\mathrm{kg} /$ Volume $\left.\mathrm{m}^{3}\right)$.

Pengumpulan data primer dilaksanakan selama 7 hari berturut-turut pada setiap pasar Unit Pelaksana Teknis Daerah (UPTD) di wilayah kota Bandar Lampung, yaitu Pasar Panjang, Pasar Cimeng, Pasar Kangkung, Pasar Tamin, Pasar Gintung, Pasar Smep, Pasar Bawah, Pasar Tugu dan Pasar Way Kandis. Sedangkan sampel sampah diambil di tempat penampungan sampah (TPS) sampah dan diukur setiap pagi hari. Peralatan dan perlengkapan yang digunakan terdiri dari timbangan, kotak sampling sampah (500 liter), meteran, serta. Perlengkapan berupa alat pemindah seperti sekop dan sarung tangan (Sugianti \& Trihadiningrum, 2008).

Data sekunder berupa cara pengelolaan sampah pasar tradisional diperoleh dari profil data pasar Unit Pelaksana Teknis Daerah (UPTD di Kota Bandar Lampung dan mencocokannya dengan kondisi pasar eksisting.

\section{HASIL}

1. Pengelolaan Sampah Pasar Tradisional

Pengelolaan sampah pasar tradisional diperoleh dari profil data pasar Unit Pelaksana Teknis Daerah (UPTD di Kota Bandar Lampung dan mencocokannya dengan kondisi pasar eksisting. Adapun pengelolaan sampah pasar di Kota Bandar Lampung dimulai dari pengumpulan sampah dari sumber yaitu kios, los dan amparan menggunakan keranjang sampah, selanjutnya dimasukan ke dalam motor trailer roda 3 dan mengangkut ke TPS. Dari TPS, sampah diangkut menggunakan dump truck sampah/amrol truck menuju TPA Bakung. 
Karakteristik TPS di UPTD Pasar Bandar Lampung umumnya bukan merupakan tempat khusus, hanya berupa bak truk armroll yang diletakan di pasar. Pada beberapa pasar, telh disediakan tempat khusus berupa bangunan dengan pasangan bata, yaitu di Pasar Panjang, Kangkung, Tamin dan Gintung.

Pengangkutan sampah di TPS dilakukan oleh Petugas Dinas Perdagangan dengan mengguna-kan truck armroll dan dump truck. yang dimiliki Dinas Perdagangan Kota Bandar Lampung. Sampah yang sudah penuh di truk sampah dibuang di TPA Bakung, yang berjarak sekitar $3 \mathrm{~km}$ untuk pasar terdekat (Pasar Cimeng) dan $18 \mathrm{~km}$ untuk jarak terjauh (Pasar Way Kandis). Frekuensi pengangkutan sampah umumnya dilakukan 1 kali sehari, kecuali Pasar Gintung sebanyak 3 kali per hari dan Pasar Tugu sebanyak 2 kali per hari. Di TPA Bakung, sampah di buang secara open dumping dan tidak ada perlakuan pengolahan. Hanya dilakukan perata-an tumpukan dan pemadatan menggunakan bulldozer. Pada Tabel 1 disajikan sarana pengelolaan sampah (data pada tanggal 1-8 Agustus 2017).

Tabel 1. Sarana Pengelolaan Sampah di UPTD Pasar di Kota Bandar Lampung

\begin{tabular}{|c|c|c|c|c|c|c|c|c|c|c|}
\hline \multirow[b]{2}{*}{$\begin{array}{l}\mathrm{N} \\
\mathrm{O}\end{array}$} & \multirow[b]{2}{*}{ Nama pasar } & \multicolumn{9}{|c|}{ Jumlah sarana pengelolaan sampah } \\
\hline & & $\begin{array}{l}\text { Sapu } \\
\text { lidi }\end{array}$ & Sekop & $\begin{array}{l}\text { Keranja } \\
\text { ng }\end{array}$ & TPS & Seragam & Masker & $\begin{array}{l}\text { Sepatu } \\
\text { boot }\end{array}$ & Gerobak & $\begin{array}{l}\text { Motor } \\
\text { Roda } \\
\text { tiga }\end{array}$ \\
\hline 1 & Pasar Bawah & 8 & 8 & 10 & 1 & 4 & 4 & 4 & - & - \\
\hline 2 & Pasar Cimeng & 12 & 12 & 20 & 1 & 6 & 6 & 6 & - & - \\
\hline 3 & Pasar P. Gintung & 24 & 24 & 10 & 2 & 12 & 12 & 12 & - & 2 \\
\hline 4 & Pasar Kangkung & 32 & 32 & 20 & 2 & 16 & 16 & 16 & 2 & - \\
\hline 5 & Pasar Panjang & 20 & 20 & 20 & 2 & 10 & 10 & 10 & 11 & 1 \\
\hline 6 & Pasar Smep & 20 & 20 & 10 & 1 & 12 & 12 & 12 & 4 & 2 \\
\hline 7 & Pasar Tamin & 10 & 10 & 10 & 2 & 5 & 5 & 5 & - & 1 \\
\hline 8 & Pasar Tugu & 8 & 8 & 15 & 2 & 6 & 6 & 6 & 4 & - \\
\hline 9 & Pasar Way Kandis & 4 & 4 & 5 & 1 & 2 & 2 & 2 & 1 & - \\
\hline
\end{tabular}

\section{Timbulan Sampah Pasar}

Timbulan sampah UPTD pasar Kota Bandar Lampung diperoleh dari hasil pengukuran di TPS masing-masing UPTD pasar. Gambaran timbulan sampah tertinggi terdapat di Pasar Pasir Gintung dan terendah di Pasar Bawah. Jumlah produksi sampah pada setiap pasar secara beriritan adalah Pasar Pasir Gintung (11,703 kg/hari), Pasar Tugu (7,959 kg/hari), Pasar Panjang (4,026 kg/hari), Pasar Kangkung (3.997 kg/hari), Pasar Smep (3,938 kg/hari), Pasar Tamin (3,931 kg/hari), Pasar Cimeng (3,885 kg/hari), Pasar Way Kandis (3,870 kg/hari), Pasar Bawah sebesar $3.438 \mathrm{~kg} /$ hari.

Berat jenis sampah adalah perbandingan relatif antara berat $(\mathrm{kg})$ per volume (liter) sampah. Berat jenis sampah suatu wilayah harus diketahui untuk menghitung beban massa sampah yaitu volume sampah menjadi berat sampah yang harus dikelola. Berat jenis rata-rata sampah di Pasar pada UPTD Pasar Kota Bandar Lampung adalah 0,63. Timbulan sampah ratarata dari seluruh pasar UPTD Pasar Kota Bandar Lampung adalah $46.747 \mathrm{~kg} /$ hari. Sedangkan rata-rata per hari pada masing-masing pasar berkisar antara $3.438 \mathrm{~kg} /$ hari sampai dengan $11.703 \mathrm{~kg} / \mathrm{hari}$.

\section{Jenis dan Komposisi Sampah}

Komposisi sampah pasar di UPTD Pasar Kota Bandar Lampung terdiri dari sampah an-organik dan sampah organik (Tabel 2).

Komposisi sampah pasar UPTD Pasar Kota Bandar Lampung paling banyak berupa sampah organik sebesar $84,48 \%$. Sampah organik adalah sampah yang berasal dari mahluk hidup, jenis sampah ini dapat terdegradasi terutama dari jenis sayuran dan sisa makanan.

\section{Potensi Ekonomi Sampah}

Paradigma sampah adalah bahan/barang yang sudah tidak mempunyai nilai manfaat adalah tidak benar, karena sampah masih dapat digunakan untuk keperluan manusia sehingga memiliki nilai ekonomi. Gambar 1 menyajikan diagram alir potensi ekonomi yang dapat diproleh dari sampah pasar UPTD Pasar Kota Bandar Lampung. 
Tabel 2. Jenis dan Komposisi Sampah UPTD Pasar Kota Bandar Lampung Tahun 2017

\begin{tabular}{|c|c|c|c|c|c|c|c|c|c|c|c|}
\hline \multirow[t]{2}{*}{ No } & \multirow[t]{2}{*}{ Jenis Sampah } & \multicolumn{10}{|c|}{ Komposisi Sampah (\%) } \\
\hline & & $\begin{array}{l}\text { Pasar } \\
\text { Bawah }\end{array}$ & $\begin{array}{l}\text { Pasar } \\
\text { Cimeng }\end{array}$ & $\begin{array}{l}\text { Pasar P. } \\
\text { Gintung }\end{array}$ & $\begin{array}{l}\text { Pasar } \\
\text { Kangku } \\
\text { ng }\end{array}$ & $\begin{array}{l}\text { Pasar } \\
\text { Panjang }\end{array}$ & $\begin{array}{l}\text { Pasar } \\
\text { Smep }\end{array}$ & $\begin{array}{l}\text { Pasar } \\
\text { Tamin }\end{array}$ & $\begin{array}{l}\text { Pasar } \\
\text { Tugu }\end{array}$ & $\begin{array}{l}\text { Pasar } \\
\text { Way } \\
\text { Kandis } \\
\end{array}$ & $\begin{array}{l}\text { Rata- } \\
\text { Rata }\end{array}$ \\
\hline \multirow[t]{4}{*}{1} & $\begin{array}{l}\text { Sampah organic } \\
\text { Sisa makanan/tulang }\end{array}$ & 3.20 & 3.80 & 3.40 & 4.20 & 3.20 & 3.00 & 3.60 & 3.20 & 3.10 & 3.41 \\
\hline & $\begin{array}{l}\text { - Sisa sayur-sayuran \& } \\
\text { Buah }\end{array}$ & 66.31 & 65.09 & 67.80 & 66.58 & 66.31 & 65.30 & 65.32 & 67.52 & 66.20 & 66.27 \\
\hline & $\begin{array}{l}\cdot \text { Kertas } \\
\cdot \text { Kayu }\end{array}$ & $\begin{array}{l}12.40 \\
2.10\end{array}$ & $\begin{array}{l}12.70 \\
2.10\end{array}$ & $\begin{array}{l}11.60 \\
2.40\end{array}$ & $\begin{array}{l}12.72 \\
2.10\end{array}$ & $\begin{array}{l}12.40 \\
2.10\end{array}$ & $\begin{array}{l}12.40 \\
2.30\end{array}$ & $\begin{array}{l}13.20 \\
2.70\end{array}$ & $\begin{array}{l}12.80 \\
2.20\end{array}$ & $\begin{array}{l}12.40 \\
2.60\end{array}$ & $\begin{array}{l}12.51 \\
2.29\end{array}$ \\
\hline & Jumlah & 84.01 & 83.69 & 85.20 & 85.60 & 84.01 & 83.00 & 84.82 & 85.72 & 84.30 & 84.48 \\
\hline \multirow[t]{7}{*}{2} & Sampah anorganik & & & & & & & & & & \\
\hline & Kaleng & 0.01 & 0.02 & 0.01 & 0.02 & 0.01 & 0.06 & 0.01 & 0.02 & 0.01 & 0.02 \\
\hline & - Plastik & 15.00 & 15.31 & 13.80 & 13.40 & 15.00 & 15.90 & 14.20 & 13.30 & 14.80 & 14.52 \\
\hline & - Karung & 0.90 & 0.90 & 0.91 & 0.90 & 0.90 & 0.94 & 0.84 & 0.88 & 0.81 & 0.89 \\
\hline & . Kaca & 0.05 & 0.05 & 0.05 & 0.05 & 0.05 & 0.05 & 0.07 & 0.05 & 0.05 & 0.05 \\
\hline & - Busa & 0.03 & 0.03 & 0.03 & 0.03 & 0.03 & 0.05 & 0.06 & 0.03 & 0.03 & 0.04 \\
\hline & Jumlah & 15.99 & 16.31 & 14.80 & 14.40 & 15.99 & 17.00 & 15.18 & 14.28 & 15.70 & 15.52 \\
\hline
\end{tabular}

Berdasarkan Gambar 1 dapat diketahui bahwa sampah organik dapat diolah dengan cara komposting dan biogas, sedangkan sampah an-organik dapat dikumpulkan dan dijual. Harga sampah berkisar antara Rp. 50 sampai dengan Rp. 1000 per $\mathrm{kg}$ (berdasarkan hasil wawancara dengan pengepul sampah di kota Bandar Lampung). Potensi ekonomi dari sampah juga disampaikan oleh Oswarii T, Suaryanto DA (2006) dan Doddy Ari Suryanto (2005). Potensi ekonomi dapat dihitung dengan cara mengalikan harga sampah dengan jumlah timbulan sampah. Pada Tabel 3 disajikan potensi ekonomi dari sampah UPTD Pasar Kota Bandar Lampung.

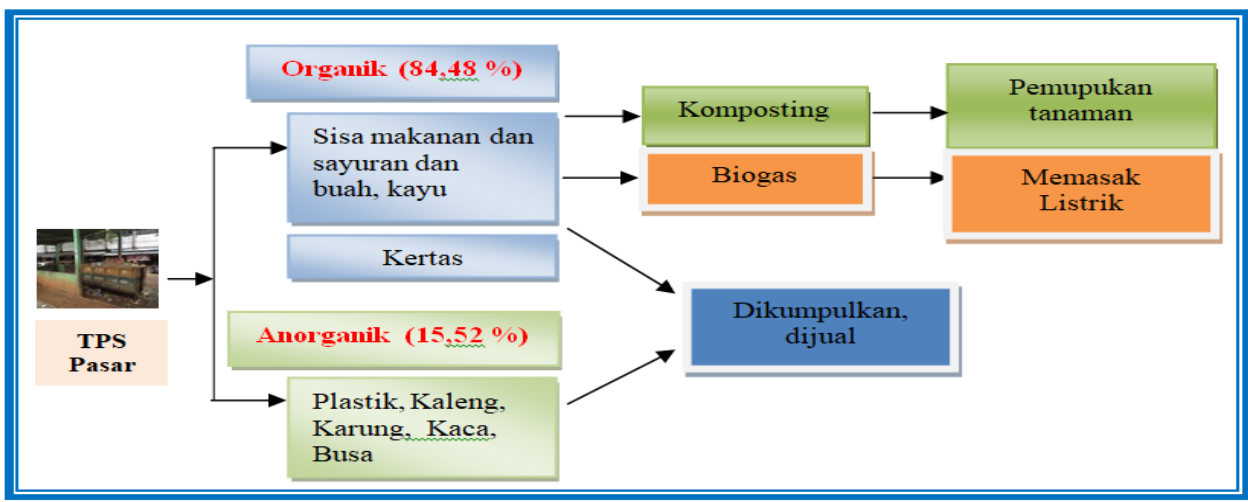

Gambar 1. Diagram Potensi Ekonomi Sampah Pasar di UPTD Pasar Kota Bandar Lampung Tahun 2017

Berdasarkan tabel 3 potensi ekonomi sampah UPTD Pasar Kota Bandar Lampung sebesar Rp. 12.938.816/hari atau Rp. 388.164.480/bulan dan Rp. 4.657.973.760/tahun.

\section{PEMBAHASAN}

1. Pengelolaan Sampah Pasar Tradisional Jumlah sarana pengelolaan sampah (Tabel 1) setiap pasar berbeda-beda jumlahnya, namun sebagian besar pasar telah memiliki sarana pengelolaan sampah. Pengelolaan sampah seperti diuraikan di atas belum sesuai dengan amanah UU Pengelolaan Sampah No. 18 Tahun
2008 dan Peraturan Daerah Kota Bandar Lampung No. 5 Tahun 2015 tentang Pengelolaan Sampah di Kota Bandar Lampung. Menurut UU No. 18 Tahun 2008, pengelolaan sampah diselenggarakan berdasarkan asas tanggung jawab, asas berkelanjutan, asas manfaat, asas keadilan, asas kesadaran, asas kebersamaan, asas keselamatan, asas keamanan, dan asas nilai ekonomi. Pengelolaan sampah juga bertujuan untuk meningkatkan kesehatan masyarakat dan kualitas lingkungan serta menjadikan sampah sebagai sumber daya (UU No 8/2008). 
Tabel 3. Potensi Ekonomi Sampah Pasar di UPTD Pasar Kota Bandar Lampung

\begin{tabular}{llllll}
\hline \multirow{2}{*}{ No } & Jenis Sampah & $\begin{array}{l}\text { Rata-Rata Komposisi } \\
\text { Sampah Pasar (\%) }\end{array}$ & $\begin{array}{l}\text { Rata-Rata Timbulan } \\
\text { Sampah (Kg)/Hari }\end{array}$ & Harga Sampah (Rp.) & Jumlah (Rp) \\
\hline 1 & Sisa makanan/tulang & 3.41 & 1,595 & 200 & 318,918 \\
2 & Sisa sayur-sayuran & 66.27 & 30,979 & 50 & $1,548,962$ \\
3 & Kertas & 12.51 & 5,850 & 700 & $4,094,726$ \\
4 & Kayu & 2.29 & 1,070 & 100 & 106,999 \\
5 & Kaleng & 0.02 & 9 & 800 & 7,064 \\
6 & Plastik & 14.52 & 6,789 & 1000 & $6,789,223$ \\
7 & Karung & 0.89 & 214 & 150 & 62,174 \\
8 & Pecahan botol/Kaca & 0.05 & 17 & 100 & 2,441 \\
9 & Busa & 0.04 & 46,747 & 500 & 8,311 \\
\hline & Total & 100.00 & & $12,938,816$ \\
\hline
\end{tabular}

Mengacu kepada kedua peraturan perundangan tersebut, Pemerintah Kota Bandar Lampung khususnya Dinas Perdagangan dan UPTD Pasar berkewajiban melakukan pengelolaan pasar yang terdiri atas pengurangan sampah dan penanganan sampah. Pengurangan sampah dilakukan meliputi beberapa kegiatan : (a) pembatasan timbulan sampah; (b) pendauran ulang sampah; dan/atau (c) pemanfaatan kembali sampah. Secara konseptual, kegiatan pengelolaan sampah yang dapat dilakukan pada level individual rumah tangga antara lain meliputi kegiatan pemilahan, komposting, biogas, pembuatan handicraft berbahan baku sampah, dan koleksi recyclable material dalam bank sampah (Wahyono, 2018).

Oleh karena itu, selayaknya UPTD pasar Kota Bandar Lampung meningkatkan dan mengusulkan sarana dan prasarana karena jumlah, jenis dan kualitasnya yang masih belum mencukupi (Tabel 1). Kurangnya sarana dan prasarana menjadi salah satu faktor yang menyebabkan belum terlaksananya pengelolaan sampah yang baik, sesuai dengan amanah Undang-Undang Tentang Pengelolaan Sampah No. 18 Tahun 2008 dan Peraturan Daerah Kota Bandar Lampung No. 5 Tahun 2015 Tentang Pengelolaan Sampah di Kota Bandar Lampung (Pemerintah Daerah Provinsi Lampung, 2015).

\section{Timbulan Sampah Pasar}

Terdapat perbedaan jumlah timbulan sampah pada masing-masing pasar di Kota Bandar Lampung. Hal ini disebabkan oleh perbedaan jumlah pedagang toko/kios, los dan amparan, khusunya pada pedagang los dan amparan yang didominasi oleh komoditi buah-buahan dan sayur-mayur. Timbulan sampah digunakan untuk perencanaan kebutuhan sarana dan prasarana sampah, seperti jumlah wadah, gerobak/motor sampah, TPS dan TPA. Informasi timbulan sampah sangat dibutuhkan untuk kepentingan perencanaan dan pelaksanaan pengelolaan sampah yang terpadu.

Berdasarkan penelitian ini disimpulkan bahwa variasi jumlah timbulan sampah dipengaruhi oleh jumlah pedagang toko/kios, los, amparan dan sifat biologis-kimia dari sampah setiap pasar UPTD Pasar Kota Bandar Lampung.

\section{Jenis dan Komposisi Sampah}

Sebagaimana dijelaskan dalam Tabel 2, sebagian besar komposisi sampah UPTD Pasar Kota Bandar Lampung berupa sampah organik $(84,48 \%)$, yaitu jenis sampah ini dapat terdegradasi terutama dari jenis sayuran dan sisa makanan. Setelah mengetahui komposisi sampah organik dapat dilakukan pengelolaan sampah yang menghendaki kecepatan, baik dalam pengumpulan, pembuangan maupun pengangkutannya. Keterlambatan pengelolaan sampah mengakibatkan terjadinya pembusukan yang dapat menghasilkan bau menyengat akibat ammoniak, dan asam-asamvolatil lainnya. Selain itu, dihasilkan pula gas-gas hasil dekomposisi seperti gas metan dan sejenisnya yang membahayakan keselamatan bila tidak ditangani secara baik.

Sampah anorganik (15,52\%) berasal dari sisa proses aktivitas manusia, seperti plastik, kertas, kaca, kaleng, dan lain-lain. Sampah anorganik sebaiknya didaur ulang, apabila tidak maka diperlukan proses lain untuk memusnahkannya seperti pembakaran, namun pembakaran juga memerlukan penanganan lebih lanjut dan berpotensi sebagai sumber pencemaran udara yang bermasalah. 
Jenis dan komposisi sampah merupakan komponen penting dalam merancang dan melaksanakan pengelolaan sampah. pengelolaan sampah bertujuan mengubah sampah menjadi bentuk yang tidak mengganggu dan memperkecil volume sehingga mudah dikelola (Jazani et al., 2017; Nugroho et al., 2018). Jenis dan komposisi sampah UPTD Pasar Kota Bandar Lampung berhubungan erat dengan pengelolaan sampah dengan konsep $3 R$. Konsep $3 R$ adalah suatu upaya untuk mengurangi volume sampah atau merubah bentuk menjadi lebih bermanfaat, antara lain dengan cara pengomposan, penghancuran, pengeringan dan pendaurulangan.

\section{Potensi Ekonomi Sampah}

Potensi pemanfaatan komponen sampah dibagi menjadi sampah organik, sampah kertas dan sampah plastik (Rahayu \& Sukmono, 2013). Dari Gambar 1 dapat diketahui sampah organik dapat diolah dengan cara komposting dan biogas, sedangkan sampah an-organik dapat dikumpulkan dan dijual. Dengan cara mengalikan harga sampah dengan jumlah timbulan sampah yang terdapat di pasar UPTD Pasar Kota Bandar Lampung maka potensi ekonomi sampah yang dapat peroleh sebesar Rp. 12.938.816/hari (Rp. 388.164.480/bulan dan Rp. 4.657.973.760/tahun). Potensi ekonomi sampah pasar UPTD Pasar Kota Bandar Lampung didapatkan dari variabel jumlah timbulan sampah, variabel jenis dan komposisi sampah dan variabel harga sampah.

Potensi Ekonomi Sampah Pasar di UPTD Pasar Kota Bandar Lampung merupakan sampah organik dapat diolah dengan cara komposting dan biogas, sedangkan sampah an-organik dapat dikumpulkan dan dijual. Kajian potensi ekonomi sampah telah dilakukan di Kota Depok (Oswarii T, Suaryanto DA, 2006). Hasil penelitan mendapatkan bahwa potensi ekonomi sampah total Kota Depok sebesar Rp. 187.951.800/hari dan sampah pasar sebesar Rp. 41.368.191/hari. Potensi ini diperoleh dari perhitungan total sampah yang dihasilkan Kota Depok sebesar $641,36 \mathrm{~m}^{3} /$ hari, dan $141,2 \mathrm{~m}^{3} /$ hari (22,01\%) adalah sampah yang berasal dari pasar.

Nilai ekonomi sampah pasar UPTD Pasar Kota Bandar Lampung akan terwujud apabila pengelolaan sampah pasar telah menggunakan konsep Reduce, Reuse, Recycle (3R). Dengan konsep 3R dilakukan pemilahan sampah sehingga didapat sampah organik dan non organik. Sampah yang sudah dipilah mempunyai harga jual sampah yang bermanfaat secara ekonomi. Berdasarkan penelitian BPPT, komponen sampah yang mempunyai nilai tinggi untuk dimanfaatkan kembali adalah sampah kertas, logam dan gelas (Oswarii T, Suaryanto DA, 2006).

Dengan menggunakan konsep $3 R$, maka model pengelolaan sampah pasar yang di buat adalah model TPS 3R. Pada konsep 3R, pengelolaan sampah terdiri atas pengurangan dan penanganan sampah. Pengurangan sampah dilakukan melalui kegiatan pembatasan timbulan sampah, pendauran ulang sampah; dan/atau pemanfaatan kembali sampah. Menurut Peraturan Menteri Pekerjaan Umum No. 3 Tahun 2013 tentang, Persyaratan Teknis Penyediaan TPS $3 R$ adalah sebagai berikut:

a. TPS $3 \mathrm{R}$ adalah tempat dilaksanakannya kegiatan pengumpulan, pemilahan, penggunaan ulang, pendauran ulang, dan pengolahan skala kawasan.

b. TPS $3 R$ :1) Luas TPS $3 R$, lebih besar dari 200 $\mathrm{m}^{2}$; 2) Penempatan lokasi TPS $3 \mathrm{R}$ sedekat, mungkin dengan daerah pelayanan dalam radius tidak lebih dari $1 \mathrm{~km}$; 3) TPS $3 R$ dilengkapi dengan ruang pemilah, pengomposan sampah organik, gudang, zona penyangga (buffer zone) dan tidak mengganggu estetika serta lalu lintas

c. Area kerja pengelolaan sampah terpadu skala kawasan (TPS3R) yang meliputi area pembongkaran muatan gerobak, pemilahan, perajangan sampah, pengomposan, tempat/kontainer sampah residu, penyimpanan barang lapak atau barang hasil pemilahan, dan pencucian.

d. Pemisahan sampah di TPS3R dilakukan untuk beberapa jenis sampah seperti sampah kertas, plastik, logam/kaca (akan digunakan sebagai bahan daur ulang) dan sampah organik (akan digunakan sebagai bahan baku kompos).

Pembuatan kompos di TPS 3R dapat dilakukan dengan berbagai metode, antara lain Open Windrow dan Caspary. Sedangkan pembuatan kompos cair di TPS 3R dapat 
dilakukan dengan Sistem Komunal Instalasi Pengolahan Anaerobik Sampah (SIKIPAS)

\section{SIMPULAN}

Pengelolaan Sampah pasar tradisional UPTD Pasar Kota Bandar Lampung, terdiri dari fase timbulan, pewadahan, pengumpulan, dan pengangkutan yang dilakukan belum menggunakan konsep pengurangan sampah dan penanganan sampah yang diamanahkan dalam UU nomor 18 tahun 2008 tentang pengelolaan sampah, dan Peraturan Daerah Kota Bandar Lampung nomor 5 tahun 2015 tentang pengelolaan sampah di Kota Bandar Lampung.

Rata-rata timbulan sampah total sebesar $46.747 \mathrm{~kg} /$ hari, dengan komposisi utama berupa sampah organik (84,48\%). Nilai potensi ekonomi sampah sebear Rp. 12.938.816/hari atau Rp. 4.657.973.760/tahun. Model pengolahan sampah yang direkomendasikan adalah TPS 3R, yang terdiri dari area penerimaan sampah organik dan anorganik, area pemilahan sampah organik dan an organik, area pengolahan sampah sampah organik dan an organik

\section{DAFTAR PUSTAKA}

Dewi, R. S. (2008). Evaluasi Ekonomi Dan Sosial Unit Pengolahan Sampah (Ups) Kota Depok.

Doddy Ari Suryanto, D. S. (2005). Kajian potensi ekonomis dengan penerapan $3 r$ (reduce, reuse dan recycle) pada pengelolaan sampah rumah tangga di kota depok. Prosiding Seminar Nasional PESAT, DEPOK, 17-28. https://core.ac.uk/download/pdf/143963687.pdf

Fauzi, A. (2006). Ekonomi Sumber Daya Alam dan Lingkungan: Teori dan Aplikasi. Gramedia Pustaka Utama.

Jazani, O. M., Rastin, H., Formela, K., Hejna, A., Shahbazi, M., Farkiani, B., \& Saeb, M. R. (2017). An investigation on the role of GMA grafting degree on the efficiency of PET/PP-g-GMA reactive blending: morphology and mechanical properties. Polymer Bulletin, 74(11), 4483-4497. https://doi.org/10.1007/s00289-017-1962-x

Nugroho, A. S., Rahmad, R., \& Suhartoyo, S. (2018). Pemanfaatan Limbah Plastik Sebagai Energy Alternatif. Simetris: Jurnal Teknik Mesin, Elektro Dan Ilmu Komputer, 9(1), 55-60. https://doi.org/10.24176/simet.v9i1.1772

Oswarii T, Suaryanto DA, S. D. (2006). Potensi Nilai Ekonomis Pengelolaan Sampah Di Kota Depok. Jurnal Ekonomi Bisnis, 2(11), 59-69.

Pemerintah Daerah Provinsi Lampung. (2015). Peraturan Daerah Kota Bandar Lampung Nomor 05 Tahun 2015, Tentang Pengelolaan Sampah.

Purwaningrum, P. (2016). Upaya Mengurangi Timbulan Sampah Plastik Di Lingkungan. Indonesian Journal of Urban and Environmental Technology, 8(2),

141. https://doi.org/10.25105/urbanenvirotech.v8i2.1 421

Rahayu, D. E., \& Sukmono, Y. (2013). Kajian Potensi Pemanfaatan Sampah Organik Pasar berdasarkan Karakteristiknya (Studi Kasus Pasar Segiri Kota Samarinda). Jurnal Sains \&Teknologi Lingkungan, 5(2), 77-90. https://doi.org/10.20885/jstl.vol5.iss2.art2

Sugianti, I. G. A. N., \& Trihadiningrum, Y. (2008). Definisi Tempat Pengolahan Sampah Terpadu. In Prosiding Seminar Nasional Manajemen Teknologi VII. Program Studi MMT-ITS, Surabaya.

UU No 8/2008, Undang-Undang Republik Indonesia Nomor 18 Tahun 2008 Tentang Pengelolaan Sampah.

Wahyono, S. (2018). Konsep pengelolaan sampah kota dan kaji terap teknologi pengelolaannya. Prosiding Seminar Nasional Dan Konsultasi Teknologi Lingkungan, 20 September 2018, 5864. 